\title{
IMPROVING STUDENTS‘ ABILITY IN LISTENING TO A RECOUNT GENRE THROUGH SONG ANALYSIS TECHNIQUE
}

\begin{abstract}
Zarwin
University of Bengkulu

Email : zarwinos@yahoo.co.id

Abstract: This research was conducted to improve IX A grade students' ability in listening to recount genre. In doing this research the researcher applied analyzing song technique. There were 32 students involved in this research. The data of this research was taking in two ways; test and observation. In taking the observation data the researcher was helped by two English teachers to know how far that the teaching process worked. The test was used to know the students progress from cycle to cycle. The test result showed that in the cycle one there are $41.25 \%$ students still had problem with the grammar, $38.78 \%$ students still had problem with the spelling and $31.87 \%$ students had problem in area of hearing, while the average score of the student's achievement is 61.00. In the cycle two the students made improvement significantly. There were only $25.00 \%$ students still had problem with the grammar, $23.00 \%$ students had problem with spelling and $27.19 \%$ students had problem with hearing, and the average score of the students' achievement was 75.00. from the result it can be concluded that song analysis technique can improve the IXA Grade students ability in listening to a recount genre
\end{abstract}

\section{Keywords : Improving Students ‘ Ability, Recount Genre, Song Analysis.}

\begin{abstract}
Abstrak: Penelitian ini diadakan untuk meningkatkan kemampuan siswa kelas IXA dalam mendengarkan genre recount. Dalam melaksnakan penelitian ini peneliti menerapkan tehnik menganalisa lagu. Jumlah siswa yang terlibat dalam penelitian ini adalah 32 orang siswa. Data pada penelitian ini diambil dengan dua cara, yaitu test dan observasi. Untuk mengam,bil data observasi peneliti dibantu oleh dua orang guru bahasa Inggris. Hal ini dilakukan untuk mengetaahui perkembangan proses pembelajaran dari satu siklus ke siklus berikutnya. Test digunakan untuk mengetahui pencapaian siswa dari satu siklus ke siklus berikutnya. Hasil test menunjukan bahewa pada siklus pertama terdapat 41,25\% bermaslah dengan tata bahasa, 31,78\% siswa bermasalah dengan pengucapan dan 31,87\% siswa bermasalah dengan menyimak sementara nilai rata-rata siswa kelas IXA adalah 61. Pada siklus dua terdapat peningkatan yang cukup signifikan. Hanya $25 \%$ siswa bermasalah dengan tata Bahasa, $23 \%$ siswa bermasalah dengan pengucapan (spelling errors) dan 31, 87\% siswa bermasalah dengan salah dengar (slip of the ears) dari hasil tersebut dapat disimpulkan technik menganalisa lagu dapat meningkatkan kemampuan mendengar genre recount pada siswa kelas IX A.
\end{abstract}

Kata Kunci: Meningkatkan Kemampuan Siswa, Genre Recount, Analisa Lagu. 


\section{INTRODUCTION}

SMP Negeri 15 Kota Bengkulu is one of schools which still applied School Based Curriculum (KTSP) in its teaching and learning process. The students are introduced to the five genres. These genres were taught in the four skills, two cycles and four steps of teaching. But the result has not satisfactory yet. Based on the researcher observation and discussion with his colleagues it was concluded that the most difficult genre was encountered by the students was in recount genre, especially in listening to text recount.

This could be seen from their listening test in recount genre. The result was still under 4.00. (Data was taken from the VII A grade student's daily test on recount genre). In listen this genre the students often found problems with

a) The grammar. We often found when students answering the question like "When did dhe come to the village? "by" She come last week" rather than "She came last week.

Brown (1980) stated that second language learning basically involved the overcoming of the diffrences between the linguistic system -tyhe native and the target language and it becomes the cause of errors. Littlewood (1996: 23) said "when learning a foreign language, someone tends to transfer his entire native language system in the process.

In English, people usually give response in accordance with the form or the tense they are using. But because those differences they sometomes ignore the agreement they give wrong response.

b) Spelling error. We often found that the student spell Balon, Baloon when they hear the word Balloon. This happened when they answer questions from the text they listened. For example "How many balloons Rudy bought in the market?" actually the expected answer is " $H \boldsymbol{H}$ bought five balloons." In this case many students write "He bought five Baloon or Ballon.

c) Slip of the eras, based on the writer observation, and in his data quite a lot of this kind of errors may be found.

Spelling arrors happens when the listeners know and understand what they hears but they do not know how to spell the words. Usually the words are then unknown either in the source or the target language. The students most likely do not hear the distinction which they will be called on to make in the second language.

They translate the unfamilliar one into familliar one in order to be able to process what they have heard (Castein $1978: 288$ ). For example, by writing [mijut] for the word [ mute] or [wes] for [wears]

Based on the researcher observation the students usually give irrelevant answer to the question; like "What was Sandra making ?'. The expected answer actually "She was making chicken curry with rice". While the students answer were: "She was making chicken curly with rice or "She was making chicken hurry in rice.". In this case most of the students don't think about the link between Chicken and Hurry in race. The phrase that they heard is significantly different from the intended 
phrase. They change other words to make sense out of the whole phrase.

Another error often made by the students was slip of the ears. Slip of the ears are mispreception of unintended speed signal this means tha a listener report hearing, as clearly and distinctly as any correctly preceived strecth of speech something that does not correspond to the speaker's actual utterence (Bond 1999:1) slip of the ears should not be confused with slip ofthe tongue in which the speaker intend to utter one thing but erroneoudsly produce another.

Speech production errors, for example anry result in phonological segments being disordered, such as saying cooke, bare while intended to say cooc and door in the subtitution of the whole words or malapropisms such as saying a cook and denish heard s coconut denish (Fay \& Cutler 1977), or several type of blends reversala, or errors made by the speaker ( Bock 1996)

Accordintg to Field ( 2004:266-267). The data of slips of the ears can be analyzed at the phoneme level so called phonemic slips. Fromkin in laufer (1991:30) explained that phonemic slips are common errors in language use.

There are three types of errors in slips og the ears, especially with consonants;

a) Deletions where no consonant is herad,

b) Additions where consonant is inserted fro which there are no cues in the signal, and c) Subtitutions where the reported consonant resembles thhe target one. With vowels, there is an assumtion that stressed syllables are much less prone to misinterpretation that the unstyressed words.

Several methods and techniques of teaching has been done to improve this problem but no one of them run well. So in this case the researcher treid to overcome the problem by using song analysis technique. Songs are assumed can motivate students in learning language. Children of all ages enjoy listening to songs, and singing and learning with it. That is why music is an essential part of the teaching learning process for young learners. All kinds of songs - from traditional to pop ones - can be used by the teacher (Gayne 2000).

Further Gayne (2000) said the point is that the teacher should select - or compose - songs which can be used either for singing together or for action. The best one is of course, those that can be used for both singing and doing some action.

(Anugrahwati. $2000: 12$ ) says that the objectives of using songs in the classroom are : 1) to associate action and object with words, 2) to internalize English sounds,3)to develop a sense of rhythm, 3)to recognize parts of the body.

Furthermore (Anugrahwati 2000) said that there are some points to remember when selecting songs for young learners. They are:

1) Are the words clear enough ?

2) Is language to difficult ? 
3) Is the theme suitable ?

4) Is the length sufficient to reinforce the language point?

Kasihani (2000: 18) noted that the teachers should always integrate song with the lesson they are teaching, and as with games, it needs to explain to the students before they listen to the song. Here are the steps in using songs in the classroom;

1. Tell the students the title of the song.

2. Play or sings the song once, let the students just listen to it, without doing anything.

3. Give them the words of the songs.

4. Read the words slowly, and let the students repeat the words.

5. Sing the whole songs together with the students slowly.

6. Repeat the whole song, this time using the normal speed.

7. If the song an action song, have the students stand in a circle, and do the action with your example.

Based on the the description and the problem above this action research attempt to adress the following question; 1). Can song analysis technique improve the ability of students SMP Negeri 15 Kota Bengkulu in listening to recount genre ?2). Can song analysis technique motivate the students of SMP Negeri 15 Kota Bengkulu in learning listening recount genre?

\section{The Objectives of The Research}

The objectives of the research were:

1) To prove whether the song analysis technique can improve the student's ability in answering listening task in recount genre.
2) To know whether the song analysis technique can motivate the students learning listening in recount genre

\section{Significance of the Research}

The result of this research is hopefully having benefit as reference and information about teaching recount genre. For SMP 15 English teachers this research can be as a feed back to improve their teaching technique. This research is also hoped can motivate the teachers in order they can find other technique of how to motivate their students.

\section{METHOD}

\section{Participants and contexts}

The aperticipant of this study were 32 students thay ere IX A grade styudents of SMP 15 Kota Bengkulu. They were consist of 12 male and 21 famela. This calss was taken because it was representative enogh as the sample of the research. This class was considered to the active class in SMP Negeri 15 Kota Bengkulu. The researcher took this class to make sure that the data taken did not change because of the absence of the students.

\section{Design and procedure}

This research used model collaborative participatory classroom action research. It was conducted in IX A grade students by total samples were 32 students. Each cycle consist of Planning, Action / Observation, Reflection and Revise plan as the following diagram: 


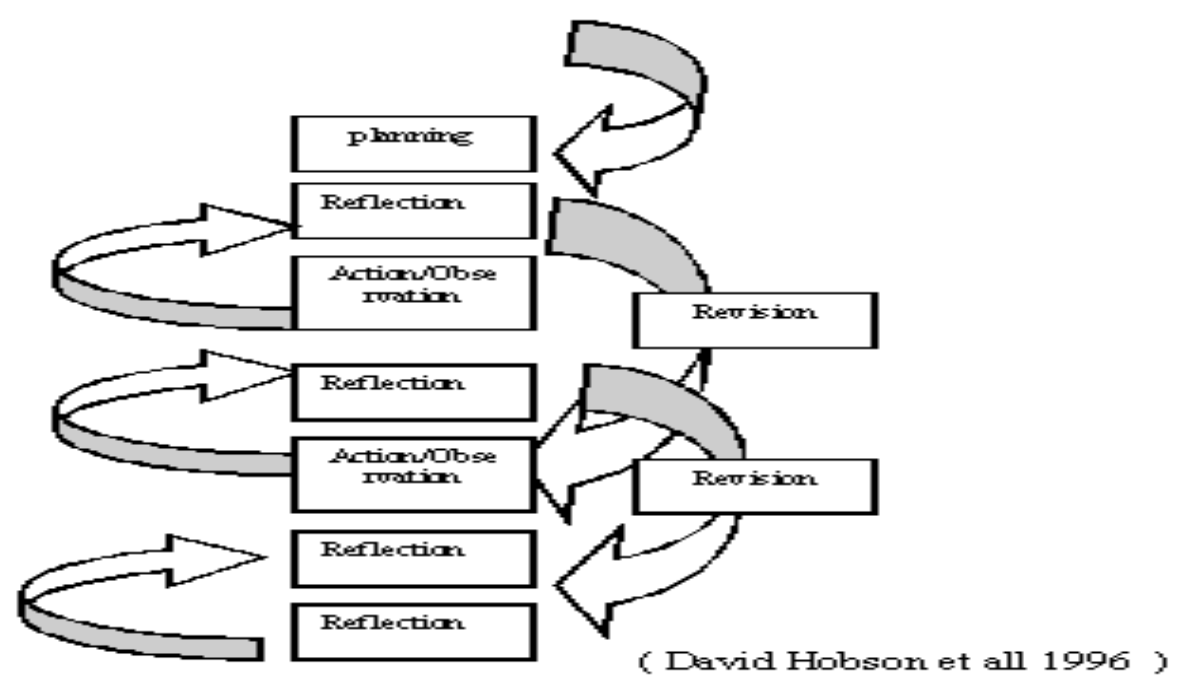

The instruments of this research were;

the objectives of the activities. Before the

1) Test, to measure the students' achievement from cycle to cycle.

2) Observation, to know how well the teaching and learning process was going on.

The indicators of the achievement are;

1. The improvement of the students test achievement from one cycle to another cycle and it will be evaluated form the formative test.

2. The motivation of the students in learning process increasingly make progress, this was proved by questionnaire which was given at the end of this study.

3. The involvement of the students both in group and individually during the process of teaching learning activity, this was proved by teachers' observation.

\section{FINDING AND DISCUSSION}

\section{Implementation of Cycle 1}

First activity: The researcher gave the theme that would be used by the students in their listening. The teacher explains about students come to the main activities, the teacher brainstorm the students a song; the song was "Right here waiting "by Richard Mark. In this case the teacher gave model of how to analyze the grammar, the function of the text and the purpose of the speaker, then the teacher and the students sang the song together The objective of this step is to motivate and focus the student with the subject matter.

Second activity, the researcher explained about the objective of the teaching and learning activities. The objective was answering question based on the song they would hear. Then the teacher gave an incomplete song text to the students. After that, the teacher turned the song on and the students worked in pairs to find the missing words of the song they heard. The title of the song is "Sad movies “.

Each pairs was given different words to analyze. Students A analyze the verb and the students B analyze the pronunciation of the certain word. The verb that the students 
analyzed was in the past form because they would hear the story in the past event. During the work the students were not allowed to discuss about their work.

The objective of this activity was to let the students discuss about the words they analyzed by themselves. After that the students change their work with their pairs and analyze some mistake they wrote. During discussion teacher guided the students to find the real meaning of those words and the category of the words. After that the teacher gave a chance to the students to practice to pronounce the word in some sentence.
The second step was finding the event in the song and arranges them in a good order. The purpose of this step was to get the stream of consciousness of the song story, so they could understand the story happened in the song.

The last step was listening to the story and the teacher gave them some questions to answer.

\section{Result in Cycle I}

Based on the implementation of cycle one there were two conclusions can be drawn; a) the result of formative test and b) the result of observation.

Table 2. The Destribution of the Students Errors Based on the Type in Cycle 2

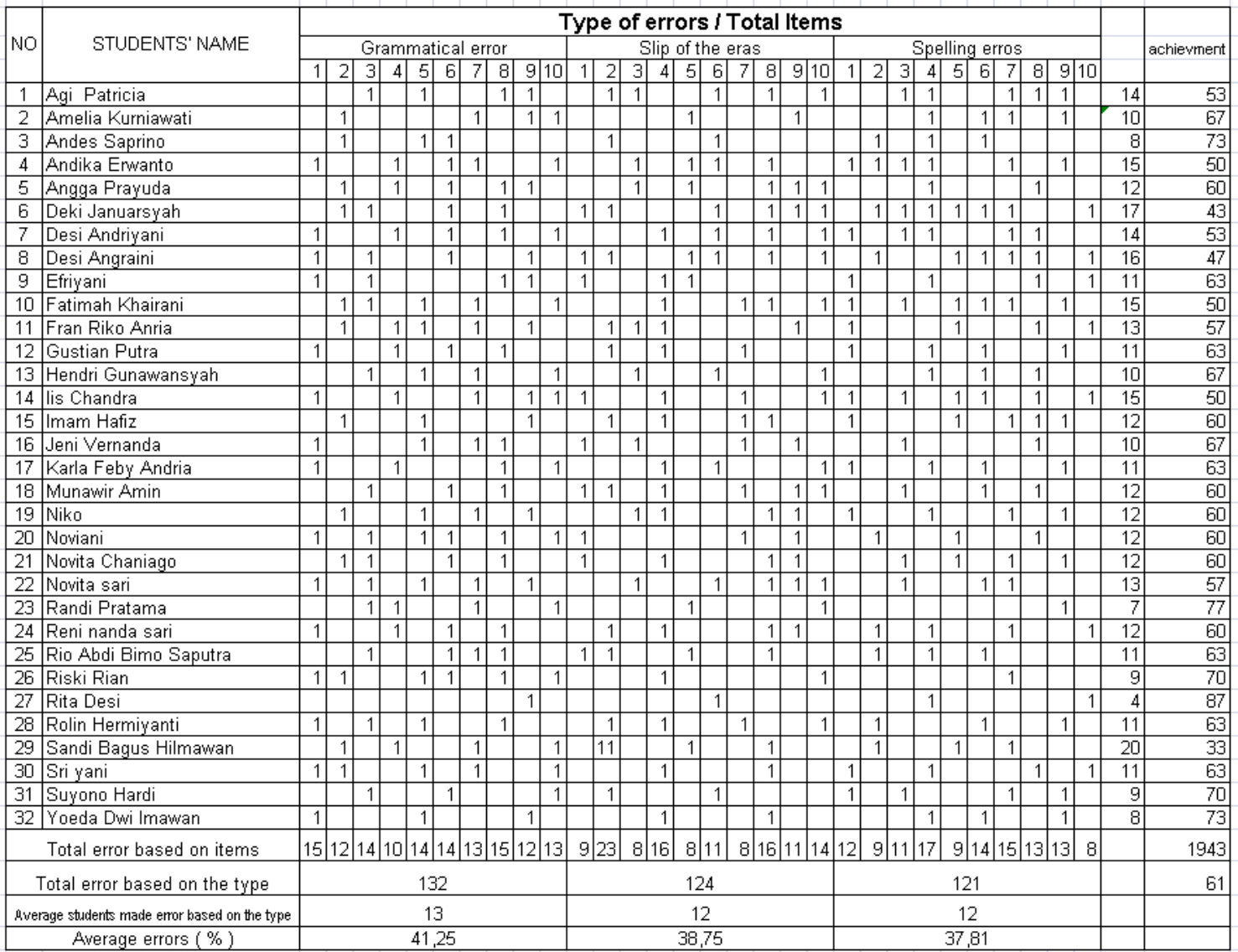


The result of the result showed that in the cycle one there are $41.25 \%$ students still had problem with the grammar, $38.78 \%$ students still had problem with the spelling and $31.87 \%$ students had problem in area of hearing, while the average score of the students' achievement was 61 . This is not satisfactory yet, because according to the standard minimum criteria is around 75 to 100. If we refers to the standard minimum criteria in SMP 15, it is enough (standard minimum criteria is 56).

\section{Observation Result}

Based on the observation result iot was obtained that the observer I gave score 34,40 the observer II gave score 3,20 so the total score of both observers were : 3,30 . According to Sudjana (1991), this score showed that the process of teaching and learning was good but somehow there were some process need to improve.

\section{Reflection}

From the test results it was found that there were thirty students still had problem with form and language (grammar). The most error made by the students was the use of tense agreement.

Question in past form sometimes answered by present form. Such as; how did the writer feel? The expected answer is; she felt surprise but the students answer was she feels surprise. In area of spelling there are 12 students made errors. These errors happened because of the unfamiliar words.

The students actually knew the words but they didn't know how to spell the words. As the consequences, they translate the unfamiliar sounds into familiar one in order to be able to process what they have heard, such as; "The writer see" written as "the water sea". Beside the spelling errors, the slip of the ears was also dominant. This occurred because the students were trying to edit what they heard into meaningful utterance and it changed other words to make sense out of the whole phrases. The words were usually meaningless. Such as; "She felt surprise"

From the observation results the researcher and the observers tried to analyze the problems of how the result was not satisfied yet. From discussion, the researcher and the observers concluded that there were several factor made the teaching process was not so satisfactory yet, they were;

a) Time organization was not so accurate.

b) The classroom activity was relatively still dominated by the teacher.

To overcome these problems the researcher together with the observers made some revision for the next cycle by; a) managing the time more accurate, b) more focus on learning community to give students more time to share and time allocation was added into 3 X 40 minutes (three period of study).

Based on the weakneses from cycle one the researcher design cycle two to improve the weakneses in cycle one. The setting of the cycle two was the same as cycle one it was in the class IX A. 


\section{Implementation}

First Activity: In this activity the teacher first asking about the past activities that the students do during their holiday. This activity is to brainstorm the students about the past event. This activity lasted for about 15 minutes. The teacher and the students then have small discussion about the tense that they use in when they told about their experiences

Second Activity: This activity was just the same as the first cycle at first, the teacher explained about the objective of the teaching and learning activities. The main purpose of this activity was answering the questions based on the text they hear. Their answering must correct both in grammar or spelling. To avoid spending the time, the first step was the teacher separates the students into two big groups. The first group guessed the missing grammar from the song they heard and another group analyzed the spelling of the grammar in the song they heard. In this activity the song that the students analyzed was "Yesterday "by the Beatles. The objective of this activity to teach the students both grammar and spelling of the text

The second step was modelling text. The students in each group discuss about their works this activity lasted for about 25 minutes. And then they were asked to come back to their pairs. Each student shows their work to their pairs and then matched it with their works. To make sure whether their work correct or not, the teacher then asked student to find the meaning of the words in their dictionary.

The third step was joint construction of the text. The teacher gave the students a text. The exercises of the text were close procedure. The students are required to fill in the blank in the text with the suitable verb and then change the verb into the past form. After completing the text the students were asked to answer the questions from the text read. This activity was focus on the tense and to remain the students about generic structure of recount text (recount genre). The teacher together with the students then discussed about the verb they read.

The forth step was individual construction of the text. The teacher asked the students to listen to the text that read by the teacher, the students then answered the question given by a long answer. This activity was design to search for the errors made by the students when the answer the questions based on the text they heard.

\section{Result in Cycle II}

Based on the implementation of cycle two there were two conclusions can be drawn;
a) The result of formative test.
b) The result of observation. 
Table 2: The Distribution of the Students Errors Based on the Type in Cycle

\begin{tabular}{|c|c|c|c|c|c|c|c|c|c|c|c|c|c|c|c|c|c|c|c|c|c|c|c|c|}
\hline \multirow{3}{*}{ NO } & \multirow{3}{*}{ STUDENTS' NAME } & \multicolumn{21}{|c|}{ Type of errors I Total Items } & & \multirow{3}{*}{ achievment } \\
\hline & & \multicolumn{7}{|c|}{ Grammatical error } & \multicolumn{6}{|c|}{\begin{tabular}{|c|} 
Slip of the eras \\
\end{tabular}} & \multicolumn{8}{|c|}{ Spelling erros } & & \\
\hline & & 1 & \begin{tabular}{l|l}
2 & 3 \\
\end{tabular} & \begin{tabular}{|l|l|}
3 & 4 \\
\end{tabular} & \begin{tabular}{l|l}
5 & 6 \\
\end{tabular} & \begin{tabular}{l|l|l|}
6 & 7 & 8 \\
\end{tabular} & \begin{tabular}{l|l|l|}
8 & 9 & 1
\end{tabular} & 10 & \begin{tabular}{l|l}
1 & 2 \\
\end{tabular} & 3 & \begin{tabular}{|l|l}
4 \\
\end{tabular} & \begin{tabular}{l|l|}
5 & 6 \\
\end{tabular} & 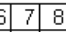 & \begin{tabular}{l|l|l|}
8 & 9 & 10 \\
\end{tabular} & 1 & 2 & 3 & & \begin{tabular}{l|l|l}
5 & 6 \\
\end{tabular} & \begin{tabular}{|l|l|l|l}
7 & 8 \\
\end{tabular} & & 10 & & \\
\hline 1 & Agi Patricia & & 1 & 1 1 & & & & & 1 & 1 & & & & \begin{tabular}{l|l|l}
1 & 1 \\
\end{tabular} & 1 & & 1 & 1 & & \begin{tabular}{|l|l}
1 & 1 \\
\end{tabular} & \begin{tabular}{l|l|}
1 & 1 \\
\end{tabular} & & 10 & 67 \\
\hline 2 & Amelia Kurniawati & & 1 & & & 1 & 1 & 1 & & & & 1 & & \begin{tabular}{|c|} 
\\
\end{tabular} & & & & 1 & 1 & 1 & \begin{tabular}{l|l} 
& 1 \\
\end{tabular} & & 10 & 67 \\
\hline 3 & Andes Saprino & & & & \begin{tabular}{c|c}
1 & 1 \\
\end{tabular} & $1 \mid$ & & & 1 & & & & & 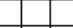 & & 1 & & a & 1 & \begin{tabular}{|l|lll} 
& \\
\end{tabular} & & & 5 & 83 \\
\hline 4 & Andika Erwanto & & & 1. & & $11_{1} 1$ & & 1 & & 1 & & \begin{tabular}{l|l|}
1 & 1 \\
\end{tabular} & & 1 & 1 & & 1 & 1 & & 1 & & & 12 & 60 \\
\hline 5 & Angga Prayuda & & 1 & & & & 1 & & & 1 & & \begin{tabular}{l|l|}
1 & \\
\end{tabular} & & \begin{tabular}{l|l|l}
1 & 1 & 1 \\
\end{tabular} & \begin{tabular}{l|l|l}
1 & & \\
\end{tabular} & & & 1 & & \begin{tabular}{l|l} 
& 1 \\
\end{tabular} & 1 & & 9 & 70 \\
\hline 6 & Deki Januarsyah & & \begin{tabular}{l|l}
1 & 1 \\
\end{tabular} & & & 1 & & & 1 & & & \begin{tabular}{l|l|} 
& 1 \\
\end{tabular} & 1 & & & 1 & & & 1 & & +1 & 1 & 8 & 73 \\
\hline 7 & Desi Andriyani & 1 & & 1 & & 1 & 1 & 1 & & & 1 & & & 1 & 1 & & 1 & 1 & & 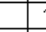 & 1 & & 11 & 63 \\
\hline 8 & Desi Angraini & & 1 & 1 & & & 1 & & \begin{tabular}{l|l}
1 & 1 \\
\end{tabular} & & & \begin{tabular}{l|l|}
1 & 1 \\
\end{tabular} & 1 & 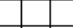 & & 1 & & & 1 & 1 & & 1 & 10 & 67 \\
\hline 9 & Efriyani & & \begin{tabular}{l|l} 
& 1 \\
\end{tabular} & 1 & & 1 & 1 & & \begin{tabular}{l|l}
1 \\
\end{tabular} & & 1 & \begin{tabular}{l|l|}
1 & \\
\end{tabular} & & & 1 & & & 1 & & & \begin{tabular}{l|l|}
1 & \\
\end{tabular} & 1 & 9 & 70 \\
\hline 10 & Fatimah Khairani & & \begin{tabular}{l|l}
1 & \\
\end{tabular} & & & & & 1 & & & & & \begin{tabular}{l|l|}
1 & 1 \\
\end{tabular} & 1 & \begin{tabular}{c|c|}
1 & \\
\end{tabular} & & & & 1 & & \begin{tabular}{l|l|} 
& 1 \\
\end{tabular} & & 7 & 77 \\
\hline 11 & Fran Riko Anria & & 1 & 1 & & 1 & 11 & & 1 & & & & & \begin{tabular}{l|l|} 
& 1 \\
\end{tabular} & & & & & 1 & & \begin{tabular}{l|l|}
1 & \\
\end{tabular} & 1 & 9 & 70 \\
\hline 12 & Gustian Putra & & & & & \begin{tabular}{l|l} 
& 1 \\
\end{tabular} & 1 & & 1 & & 1 & & 1 & & & & & 1 & 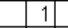 & & \begin{tabular}{l|l|} 
& 1 \\
\end{tabular} & & 7 & 77 \\
\hline 13 & Hendri Gunawansyah & & & & 1 & & & 1 & & & & & & & 1 & & & & 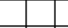 & & 10 & 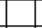 & 4 & 87 \\
\hline 14 & lis Chandra & & & 1 & & & & & & & & & 1 & & \begin{tabular}{l|l|}
1 & 1 \\
\end{tabular} & & 1 & & 1 & & $\begin{array}{ll} \\
\end{array}$ & 1 & 7 & 77 \\
\hline 15 & Imam Hafiz & & 1 & & & & 1 & & & & & & \begin{tabular}{l|l}
1 & 1 \\
\end{tabular} & 1 & 1 & & & & 1 & & 1 & & 7 & 77 \\
\hline 16 & Jeni Vernanda & & & & 1 & & & & 1 & 1 & & & \begin{tabular}{l|l}
1 & \\
\end{tabular} & \begin{tabular}{l|l} 
& 1 \\
\end{tabular} & & & 1 & & & & & & 6 & 80 \\
\hline 17 & Karla Feby Andria & & & 1 & & 1 & 1 & 1 & & & & 1 & 1 & & \begin{tabular}{|l|l|}
1 & 1 \\
\end{tabular} & & & & 1 & & 1 & & 8 & 73 \\
\hline 18 & Munawir Amin & & 1 & & & 1 & 1 & & & & & & & \begin{tabular}{l|l}
1 & 1 \\
\end{tabular} & $1 \mid$ & & 1 & & 1 & & 1 & & 8 & 73 \\
\hline 19 & Niko & & 1 & & & & 1 & & & 1 & & & & 1 & 1 & & & 1 & & 1 & 1 & & 8 & 73 \\
\hline 20 & Noviani & 1 & 1 & & & 1 & 1 & 1 & & & & & \begin{tabular}{l|l}
1 & \\
\end{tabular} & & & 1 & & & & & 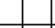 & & 6 & 80 \\
\hline 21 & Novita Chaniago & & 1 & & & 1 & 1 & & 1 & & & & & 1 & & & 1 & & 1 & 1 & 1 & & 10 & 67 \\
\hline 22 & Novita sari & & 1 & & & & 1 & & & 1 & & 1 & & 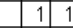 & 1 & & & & $1 \mid$ & 1 & + & & 8 & 73 \\
\hline 23 & Randi Pratama & & & 1 & & 1 & & 1 & & & & \begin{tabular}{l|l|}
1 & \\
\end{tabular} & & & 1 & & & & 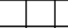 & \begin{tabular}{|l|l} 
& \\
\end{tabular} & 1 & & 6 & 80 \\
\hline 24 & Reni nanda sari & & & 1 & & 1 & 1 & & 1 & & 1 & & & 1 & & 1 & & 1 & & 1 & 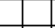 & 1 & 9 & 70 \\
\hline 25 & Rio Abdi Bimo Saputra & 1 & 1 & & & 1 & 1 & & \begin{tabular}{l|l}
1 \\
\end{tabular} & & & & & 1 & & 1 & & & 1 & & & & 7 & 77 \\
\hline 26 & Riski Rian & & \begin{tabular}{l|l}
1 & \\
\end{tabular} & & 1 & 1 & 1 & 1 & & & 1 & & & & & & & & & 1 & & & 6 & 80 \\
\hline 27 & Rita Desi & & & & & & 1 & & & & & 1 & & & & & & & & & & 1 & 3 & 90 \\
\hline 28 & Rolin Hermiyanti & & & & 1 & 1 & 1 & & 1 & & 1 & & 1 & 1 & 1 & & & & 1 & & 1 & & 8 & 73 \\
\hline 29 & Sandi Bagus Hilmawan & 1 & 1 & & & & & & & & & 1 & & & & 1 & & & & \begin{tabular}{|c|c|c|}
1 & \\
\end{tabular} & & & 5 & 83 \\
\hline 30 & Sri yani & & 1 & & 1 & & & & & & & & & 1 & 1 & & & 1 & & & 1 & 1 & 7 & 77 \\
\hline 31 & Suyono Hardi & & \begin{tabular}{l|l} 
& 1 \\
\end{tabular} & & & & & 1 & 1 & & & 1 & & & & & 1 & & & & & & 5 & 83 \\
\hline 32 & Yoeda Dwi Imawan & 1 & & & 1 & & \begin{tabular}{l|l}
1 & \\
\end{tabular} & & & & 1 & & & 1. & & & & \begin{tabular}{|l|}
1 \\
\end{tabular} & $|1|$ & & \begin{tabular}{l|l|} 
& 1 \\
\end{tabular} & + & 8 & 73 \\
\hline & Total error based on items & $\begin{array}{lll}5 & 1 \\
\end{array}$ & \begin{tabular}{l|l}
11 & 10 \\
\end{tabular} & $\begin{array}{lll}0 & 7 \\
\end{array}$ & \begin{tabular}{|l|l|}
7 & 6 \\
\end{tabular} & \begin{tabular}{l|l|l}
6 & 4 & 11 \\
\end{tabular} & \begin{tabular}{ll|l}
1 & 9 & 10 \\
\end{tabular} & 10 & \begin{tabular}{l|l}
6 & 8 \\
\end{tabular} & \begin{tabular}{|c|c|} 
& 6 \\
\end{tabular} & $7 \mid$ & \begin{tabular}{l|l|}
7 & 7 \\
\end{tabular} & \begin{tabular}{l|l|}
7 & 12 \\
\end{tabular} & \begin{tabular}{l|l|l}
12 & 6 & 10 \\
\end{tabular} & 0.8 & 7 & 8 & 11 & \begin{tabular}{l|l|l|l}
6 & 10 & 1 \\
\end{tabular} & $10 \mid 8$ & \begin{tabular}{l|l|l|}
8 & 11 \\
\end{tabular} & 8 & & 2390 \\
\hline & Total error based on the type & & & & 80 & & & & & & & 76 & & & & & & & 87 & & & & & 75 \\
\hline & erage students made error based on the type & & & & 8 & & & & & & & 8 & & & & & & & 9 & & & & & \\
\hline & Average errors $(\%)$ & & & & 25,00 & & & & & & & 23,75 & & & & & & & 27,19 & & & & & \\
\hline
\end{tabular}

From the table we can see that $25 \%$ problem are caused by grammatical errors and $27,19 \%$ were caused by spelling errors and $23,75 \%$ caused by slip of the ears. While the average score of the students' achievement was 75 . This means that there were improvement in this action although there was decreasing on the slip of the ear (mishearing). These factors can be understood. It may be caused by the level of difficulty of the text was quite different and this would be discussed on the nest action.

\section{Observation Result}

Based on the observation result we can see that the observer I gave score 3,40 the observer II gave score 3,35 so the total score of both observers were : 3,38. According to Sudan (1991), this score showed that the process of teaching and learning was good but somehow there are some processes need to improve.

\section{Reflection}

From the test results it was found that there were progress on grammar and spelling on the written, total students who made error on the grammar could be eliminated. From the data above we can see that total student who made error on grammar was 1 student of 13 students in cycle I, and the total students who made error on the spelling was 10 students of 12 students in the cycle I, while in area of slip of the ear or 
mishearing was 11 students of 12 students in the first cycle. The average score that the students should get was 76 . The researcher found that the result was already achieved the target of the achievement the writer stops this research in the cycle two The researccher felt that the techniques was sucessful enough and the research coud be stopped the research.

\section{Discussion}

Based on the finding from the two cycles it was found that teaching recount genre through song analysis made students easy to analyze every words that they hear from the native speaker talk, especially in the three areas of errors that are usually made by the students.

This finding was also in accordance with the theory of quantum teaching and learning which assumes that if the teacher wants their students become part of their work he or she must come to the students' world and then take them to their world. In the researcher mid this theory also implies that teacher must be able to understand the students need and hobby, this means that however, this technique is not suitable for those students who do not like singing

This finding also proved that song can improve students listening ability especially in those three areas of errors (grammar, spelling and mishearing). The students seem to enjoy listening to songs, and singing and learning with it.

As (Gayne 2000) says that music is an essential part of the teaching - learning process for young learners. All kinds of songs - from traditional to pop ones - can be used by the teacher Gayne (2000: 23). But the point that for those wjo want to apply this technique should select - or compose - songs which can be used either for singing together or for action. The best one is of course, those that can be used for both singing and doing some action.

In doing his research the researcher tried to implement pop kind music to motivate his students. When this first conducted the students felt that they would face the same way of teaching, this was happened in the first cycle, because the researcher explained the element of language to be learnt before playing the music.

This cycle took relatively much time because before the students came to whilst activity the researcher played previous music and it little bit took time. That was why the result was not satisfyactory yet, some of the student just enjoyed the song rather than preparing to study.

When the researcher came to the second cycle it was improved by making the group work with the different tasks. It was begun with listening to the whole song and then the students were asked to analyze some missing words in the text they had.

The objectives of this activity were, to internalize English sounds, to develop a sense of rhythm, and to recognize some vocabularies of the text they listen. The result significantly improved. This activity answers Kasihani suggestions that the teachers should always integrate song with the lesson they are teaching, and as with 
games, it needs to explain to the students before they listen to the song.

\section{CONCLUSION}

From the two cycles that the researcher conducted in this classroom action research it can be concluded ; 1) Song analysis technique can improve the ability of students SMP Negeri 15 Kota Bengkulu in listening to recount genre 2) Song analysis technique can motivate the students of SMP Negeri 15 Kota Bengkulu in learning listening recount genre

\section{REFERENCES}

Assinder W. Peer teaching peer learning Eenglish teaching forum.

Anugrahwati, Nunung ( 2004 ); teaching English through song analysis: Paper presented on training of trainer of English teacher in six provinces.

Bock, C. (1996). Unfied process spesification language: Requirment for modelling process. NSTIR 5910: National Institute and technology.

Cutler, A .\& Norris, D (1988). The role of strong syllable in segmentation for lexical access. Journal of experiment psychology: Human preception and performance.(13.3) pp 1-4

Depdiknas, (1996). Garis - garis besar program pengajaran( GBPP ) SLTP, Jakarta : Dirjen Dikdasmen.

Depdiknas.(2004). Kurikulum berbasis kompetensi .Standard kompetensi mata pelajaran Bahasa Inggris SMP dan MTs.

Depdiknas,(2004).KurikulumBerbasisKompetensi. Standar Kompetensi Mata Pelajaran Bahasa Inggris SMP dsam MTs.
Djoehana,D.(2002). Inquiry dalam pembelajaran bahasa Inggris. Paper presented on training of trainer of English teacher in six provinces.

Fay, D \& Cutler. A. (1977). Malaporism and the structure of the mental lexicon. Ling. 8.3.505-20.

Field, John. (2004) Psycholinguistic: the key concepts: New York Routledge.

Hobsar, David (1996). Classroom action research and Its application.London: Houghton Mifflin Company.

Haesley Brendan. (2003). English for communication for SLTP students. Jakarat Penerbit. Erlangga.

Kasihani. (2002). Contextual teaching and leaming (CTL) Dalam Pengajaran dan Pembelajaran Bahasa. Paper presented on training of trainer of English teacher in six provinces.

Littlewood, W, (1986). Foreign English as a second language: Language acquisition research and Its application for the classroom. New York: Cambridge University Press.

Mukarto.(2002). English on sky 1. for junior high school. JakartaPenerbit,Erlangga.

Norton, D.E. (1980). The effective teaching of language arts. London: E. Memil Publishing Company.

Paulston, C.B and M.N Brudder.(1981). Teaching English as a second language, Technique and Procedure. Boston: Little, Brown and Company.

Richard, J.C and T.S Rodgers.(1980). approach and method of english teaching. A descriptive and analysis. New York:CambridgeUniversity Press. Sudjana. (1993). Dasar - dasar evaluasi pendidikan. Jakarta Penerbit, Bumi Aksara. 